\title{
Combination Cancer Therapy of a Del1 Fragment and Cisplatin Enhanced Therapeutic Efficiency In Vivo
}

\author{
HISATAKA KITANO $^{1}$, YOH MASAOKA ${ }^{1}$, ATSUSHI MAMIYA ${ }^{1}$, \\ YUSUKE FUJIWARA $^{1}$, TOSHIO MIKI $^{2}$ and CHIAKI HIDAI ${ }^{3}$ \\ ${ }^{1}$ Division of Oral Surgery, Nihon University School of Medicine, Tokyo, Japan; \\ ${ }^{2}$ Division of Physiology, Nihon University School of Medicine, Tokyo, Japan; \\ ${ }^{3}$ Medical Education Center, Nihon University School of Medicine, Tokyo, Japan
}

\begin{abstract}
Background/Aim: Combination cancer therapy is currently under investigation. This study examined the effect of cancer combination therapy using the E3 and C1 (E3C1) domains of developmental endothelial locus-1 (Del1) and cisplatin (CDDP) in murine transplanted tumors. Materials and Methods: Mice with transplanted tumors (A431, SCCKN or SCC-4 cells) were injected intraperitoneally with CDDP and injected locally with nonviral plasmid vectors encoding E3C1. Histochemical analysis of the transplanted tumors was then performed to assess the effects on prognosis. Results: The CDDP $+E 3 C 1$ injected group had reduced tumor growth and longer survival compared to the CDDP injected group. In addition, cell death was observed in the tumor of the $C D D P+E 3 C 1$ group.. Furthermore, angiogenesis and increased blood vessels were observed together with stromal development. Conclusion: The CDDP $+E 3 C 1$ treatment resulted in improved survival and poor tumor stromal development in mice with transplanted tumors.
\end{abstract}

Cisplatin (CDDP) is currently the most essential anticancer agent in cancer chemotherapy. CDDP is used in most chemotherapy regimens for gastric, colorectal, lung and head and neck cancers. Furthermore, CDDP has shown efficacy against a wide variety of cancers. In addition, CDDP is also used as neo-adjunctive or adjunctive therapy for surgery. The history of CDDP as an anticancer agent began in 1965 when Rosenberg et al. (1) discovered the

This article is freely accessible online.

Correspondence to: Chiaki Hidai, Medical Education Center, Nihon University School of Medicine, 30-1 Ooyaguchikamichou, Itabashiku, Tokyo 173-8610, Japan. Tel: +81 339728111, Fax: +81 339728810, e-mail: hidai.chiaki@nihon-u.ac.jp

Key Words: Combination cancer therapy, developmental endothelial locus 1 , cisplatin, tumor stroma, squamous cell carcinoma. inhibitory effects of the electrolytic products of platinum electrodes on cell division in Escherichia coli (2). CDDP is understood to exhibit anticancer activity by forming DNA and covalent adducts (3-5). In its mechanism of action, CDDP forms DNA and various covalent adducts, inhibiting transcription factors and polymerase and destroying chromatin. These activities eventually lead to cell apoptosis (6-9). Williams et al. reported that administering CDDP as a single agent had a $60 \%$ effective rate against testicular cancer, with $19 \%$ of cases showing complete tumor disappearance (10). Further, Panettiere et al. reported a 25\% effective rate for CDDP single-agent administration against head and neck cancer (11). In addition, combination chemotherapies using CDDP have been reported to show efficacy against squamous cell carcinoma (SCC) of $75 \%$ or more (12-15). On the other hand, CDDP is also known to be associated with various severe side effects (nephrotoxicity, nausea, vomiting, hearing loss, weight reduction, etc.) (16-18). In addition, CDDP resistance can be induced by CDDP treatment $(19,20)$. These events represent major disadvantages to CDDP treatment.

Currently, SCC is the most common cancer type in the world. The main treatments for SCC are surgery, chemotherapy, and radiotherapy. Cancer gene therapy is also under development as a new modality (21-25). In 1991, the first clinical trial of cancer gene therapy demonstrated that genetically modified immune cells could be reintroduced into patients, and with the approval of CAR-T cell therapy by the United States Food and Drug Administration (FDA), this field has seen tremendous advances $(26,27)$. Kitano et al. attempted gene therapy against SCC explants in vivo (28, 29). Mice with explanted SCC cells were treated with the extracellular matrix protein developmental endothelial locus1 (Del1) using a non-viral vector. Dell has been shown to exhibit pro- or anti-angiogenic activities (30). Del1 is comprised of five domains: three epidermal growth factor (EGF) repeats (E1, E2, and E3) and two discoidin domains (C1 and C2) (30). The E2 domain is reported to contain 
RGD sequences, which bind to integrin receptors and support endothelial cell survival (30). The E3 domain induces endocytosis and increases the efficiency of gene transfer, and has been reported to induce apoptosis $(31,32)$. Furthermore, the $\mathrm{C} 1$ domain has been reported to cause deposition in the extracellular matrix (33). A recombinant protein comprising the $\mathrm{E} 3$ and $\mathrm{C} 1$ domains (E3C1) of Del1 was thus hypothesized to be deposited in extracellular matrix at high concentrations, induce apoptosis, and enhance the efficiency of subsequent transfections. Mice with transplanted tumors therefore received weekly local injections using DNA encoding a recombinant protein of E3C1 by a non-viral vector. As a result, transplanted SCCKN tumors showed efficient deposition of $\mathrm{E} 3 \mathrm{C} 1$, and increased gene transfer efficiency (29). In addition, 50\% of mice treated with $\mathrm{E} 3 \mathrm{C} 1$ survived for 7 weeks, whereas all mice in the control group died prior to this time point (29). Furthermore, analysis of the effects of long-term E3C1 treatment showed that $20 \%$ of E3C1-treated mice survived for 197 days, with explanted tumors resolving by day 197 in two mice (34). With transplanted A431 tumors, 33\% of mice treated with E3C1 survived more than 60 days, whereas all control mice died by day 32 (35).

Due to enhanced therapeutic response and minimal adverse effects, combination cancer therapy has recently become widespread all over the world. The aim of this study was to examine the effects of combination cancer therapy comprising cancer gene therapy using the EGF motif of Del1 and CDDP as the most commonly used chemotherapeutic agent for SCC cells. In this regard, mouse transplanted tumors were consecutively treated by E3C1 until a humane end point was reached. This study confirmed that combination therapy of $\mathrm{CDDP}+\mathrm{E} 3 \mathrm{C} 1$ inhibited the growth of SCC transplants and improved the survival of mice with transplanted tumors.

\section{Materials and Methods}

Cell lines and culture. The A431 human epidermoid squamous carcinoma cell line (ATCC: CRL-1555) was purchased from American Type Culture Collection (ATCC, Manassa, VA, USA) (36, 37). This cell line was grown in serum-free medium [60\% OptiMEM (Invitrogen, Carlsbad, CA, USA), 40\% LHC-8medium (Invitrogen)]. The SCCKN (RIKEN BioResource Research Center, Tokyo, Japan, cell number: RCB0441) $(38,39)$ human tongue squamous carcinoma cell line was kindly provided by Dr. Hayashido from the University of Hiroshima (Hiroshima, Japan). This cell line was grown in RD medium, comprised of $45 \%$ Dulbecco's modified Eagle medium (Invitrogen), 45\% RPMI 1640 medium (Invitrogen), and 10\% fetal bovine serum (Sigma, St. Louis, MO, USA). Cells were then cultured in $5 \% \mathrm{CO}_{2}$ at $37^{\circ} \mathrm{C}$. The SCC-4 human tongue squamous carcinoma cell line was purchased from ATCC (ATCC: CRL-1624) $(40,41)$. This cell line was grown in RPMI 1640 medium (Invitrogen) and 10\% fetal bovine serum. Cells were cultured in $5 \% \mathrm{CO}_{2}$ at $37^{\circ} \mathrm{C}$.
DNA constructs. Mouse Del1 complementary DNA was kindly provided by Dr. Quertermous of Stanford University (Stanford, CA, USA). A fragment encoding E3C1 (amino acids 122-316 of mouse Del1) was amplified using polymerase chain reaction with the forward primer 5'-TGTGAAGCTGAGCCTTGCAGAATGGCCG GA-3' and the reverse primer 5'-ACAGCCTGAGAGCTCACAG CCAAGAAGTT-3' to generate pcDNA3.1D (Invitrogen), a mammalian expression vector. A signal peptide sequence of the $\mathrm{E} 3 \mathrm{C} 1-$ complementary DNA was then inserted into pcDNA3.1D to generate a recombinant protein with $\mathrm{V} 5$-epitope tags at the $\mathrm{C}$-terminal ends.

Animal studies. All animal experiments performed in this study were conducted in accordance with the animal husbandry regulations of Nihon University and the US National Institutes of Health. This study was approved by the Ethics Committee of Nihon University (AP18MED023-2). NOD CB17-Prkdc scid/J mice were kept in a pathogen-free environment. For tumor explants, A431, SCCKN or SCC4 cells were first seeded in $10-\mathrm{cm}$ culture dishes overnight to reach $70-80 \%$ confluence and were harvested using a cell stripper (Asone, Tokyo, Japan) after washing with phosphate-buffered saline (PBS). The cells were then washed twice with PBS and centrifuged at $500 \times g$ for $5 \mathrm{~min}$, then resuspended in RD medium at a concentration of $1 \times 10^{7} / 100 \mathrm{ml}$. A total of $100 \mu \mathrm{l}$ of suspended cells were injected subcutaneously into the right flank of a NOD CB17-Prkde scid/J mouse. Tumor growth was measured using calipers twice a week. Tumor volume was calculated using the following formula: tumor volume (in cubic millimeters $)=\left(\right.$ width $\left.\times l_{\text {ength }}^{2}\right) / 2$. Mouse weights were calculated using the formula (whole weight - tumor volume). When tumor volume exceeded $60 \mathrm{~mm}^{3}$, treatment was initiated with CDDP (Fujifilm, Tokyo, Japan), CDDP together with the plasmid encoding $\mathrm{E} 3 \mathrm{C} 1(\mathrm{CDDP}+\mathrm{E} 3 \mathrm{C} 1)$ or pcDNA3 as a mock vector for controls. As treatment, CDDP was injected intraperitoneally at $10 \mathrm{mg} / \mathrm{kg}$ and 10 $\mu \mathrm{g}$ of DNA was injected into the tumor in $100 \mu \mathrm{L}$ increments using in vivo-jetPEI (Polyplus Transfection, San Marcos, CA, USA) once a week. When the tumor had grown to $>15 \%$ of body weight, the mouse was considered to have reached a humane end point and was therefore euthanized. Eleven days after starting treatment, all remaining mice were sacrificed under deep anesthesia with isoflurane for histological examination. On euthanasia, the tumor was immediately removed and frozen at $-80^{\circ} \mathrm{C}$, after which, $5-\mathrm{mm}$ frozen sections were prepared.

Evaluation of perfusion. Half of the mice transplanted tumor with SCC4 cells in each treatment group was injected intravenously with fluorescein-conjugated Lycopersicon esculentum (tomato) lectin (LEL) $(0.4 \mathrm{mg} / \mathrm{ml})$ (Vector Laboratories, Burlingame, CA, USA). The mice were euthanized $2 \mathrm{~min}$ after the injection. The transplanted tumors were immediately resected and placed in Optimal Cutting Temperature (OCT) compound (Sakura Finetek Japan, Tokyo, Japan). Blocks then were stored at $-80^{\circ} \mathrm{C}$. Furthermore, the other half of the mice received an intravenous injection of Black ink, and were then euthanized after $2 \mathrm{~min}$. Transplanted tumors were immediately fixed in $4 \%$ paraformaldehyde (PFA).

Immunohistochemistry. Rabbit polyclonal anti-CD31 (PECAM) antibody or anti-alpha smooth muscle actin (aSMA) antibody were purchased from Abcam (Cambridge, UK). Alexa Fluor 568-labeled goat antirabbit antibodies were purchased from Invitrogen. For immunohistochemistry, 5- $\mu \mathrm{m}$ sections were fixed with $4 \%$ PFA, incubated with primary antibodies, and then incubated with the appropriate secondary antibodies. Hoechst 33342 was used to visualize nuclei. An Axioskop 2 microscope (Carl Zeiss 
A

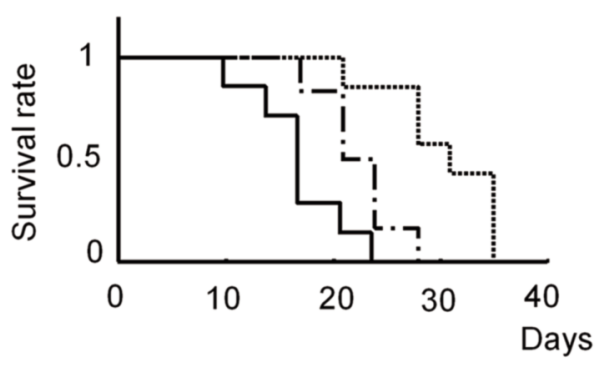

C

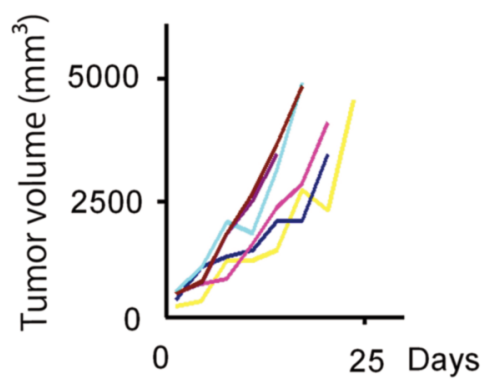

$\mathbf{E}$

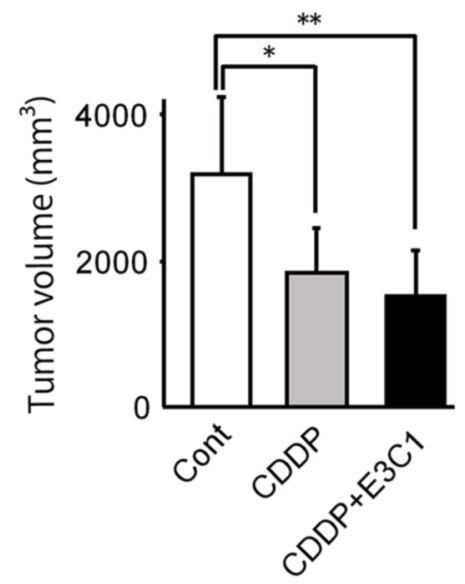

B

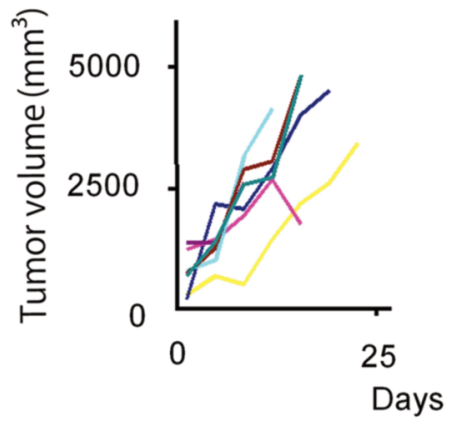

D

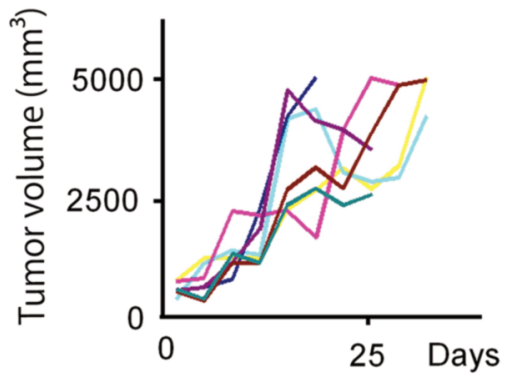

$\mathbf{F}$

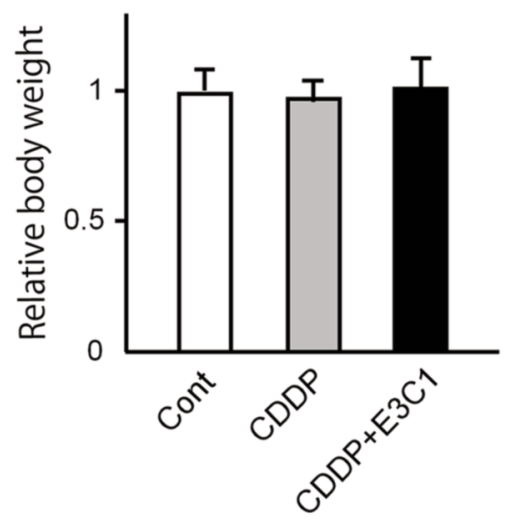

Figure 1. Effect of combination therapy for mice with transplanted A431 cells. (A) Kaplan-Meier survival curves of mice in the control group (solid line, $n=7)$, CDDP treatment group (chain line, $n=6)$ and CDDP+E3C1 treatment group (dashed line, $n=7$ ) (control vs. CDDP, $p<0.05 ;$ control vs. $C D D P+E 3 C 1, p<0.01 ; C D D P$ vs. $C D D P+E 3 C 1, p<0.05)$. (B-D) Chronological changes in tumor volume in individual mice following control $(B)$, $C D D P$ treatment $(C)$ and $C D D P+E 3 C 1$ treatment $(D)$. (E) After 11 days of treatment, comparison of tumor volumes (control vs. CDDP, $p<0.05$; control vs. CDDP+E3C1, $<<0.01)$. (F) After 11 days of treatment, comparison of mouse weights. Results are expressed as mean $\pm S D(E, F)$.

Microimaging, Welwyn Garden City, UK) equipped with an AxioCam (Carl Zeiss Microimaging) was used to observe tissues and take photographs. Fluorescence intensity was measured using Photoshop v 7.0 (Adobe Systems Incorporated, San Jose, CA). The intensity in control samples was set as 1 . Results per view are expressed as mean \pm standard deviation (SD).

Statistical analysis. Thsurvival analysis was performed by KaplanMeier log-rank test. One-way ANOVA and then Bonferoni correction were performed as appropriate. The results of except for survival analyses are expressed as mean $\pm \mathrm{SD}$. The statistical significance was defined as $* p<0.05, * * p<0.01$. Data were analyzed using the SPSS software (version 16, Chicago, IL, USA).

\section{Results}

Combination therapy with $C D D P+E 3 C 1$ prolonged survival in mice with A431-derived tumors. Mice with tumors from A431 cells were treated by control, CDDP, or CDDP+E3C1 
A

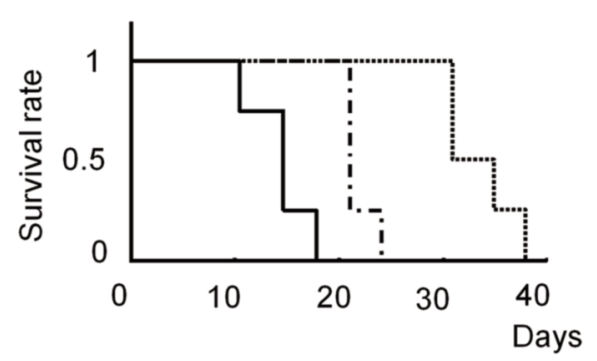

C

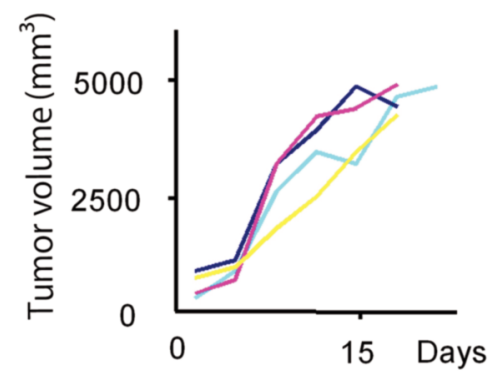

$\mathbf{E}$

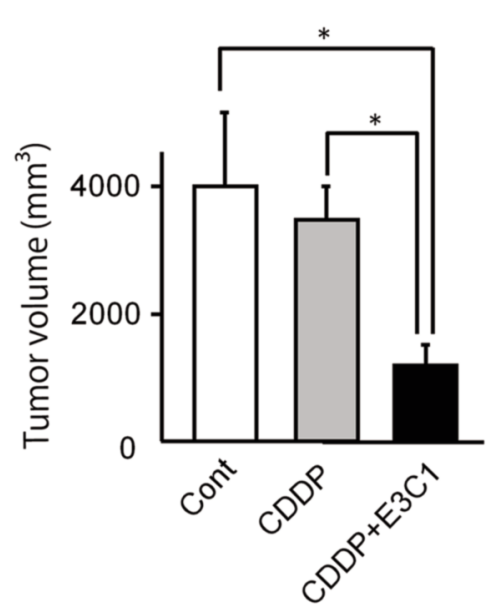

B

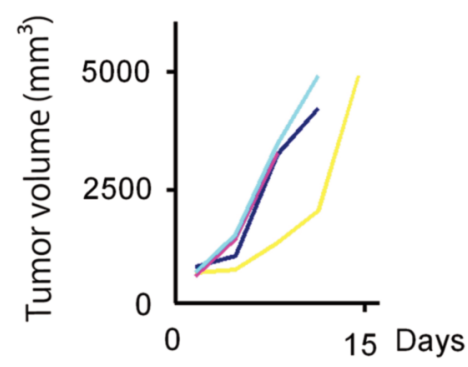

D

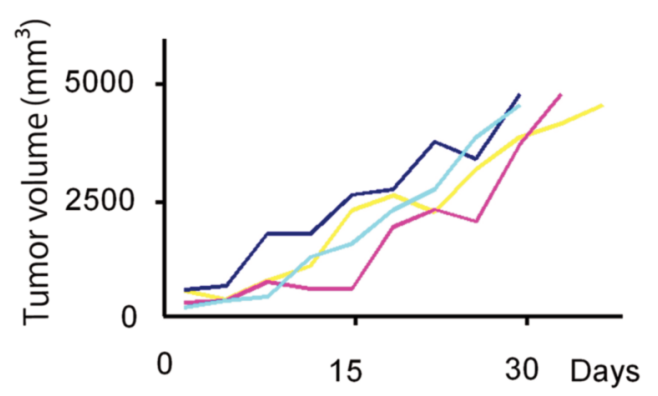

$\mathbf{F}$

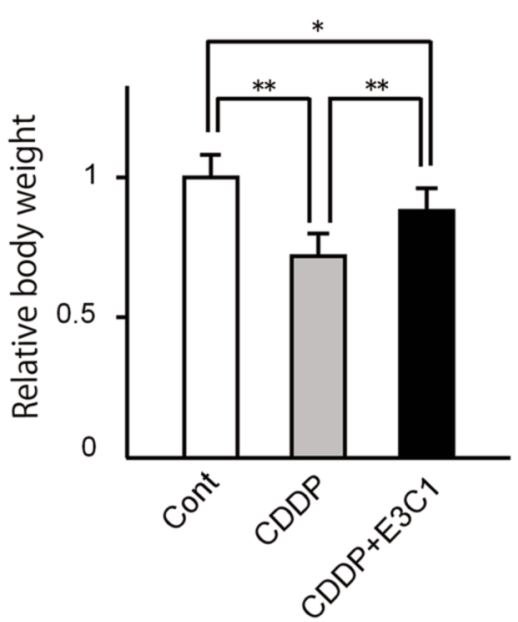

Figure 2. Effect of combination therapy for mice with transplanted SCCKN cells. (A) Kaplan-Meier survival curves of mice in the control group (solid line, $n=4)$, CDDP treatment group (chain line, $n=4)$ and CDDP $+E 3 C 1$ treatment group (dashed line, $n=4)($ control vs. CDDP, $p<0.05$; control vs. $C D D P+E 3 C 1, p<0.05 ; C D D P$ vs. $C D D P+E 3 C 1, p<0.05)$. (B-D) Chronological changes in tumor volume in individual mice following control $(B), C D D P$ treatment $(C)$ and $C D D P+E 3 C 1$ treatment $(D)$. (E) After 11 days of treatment, comparison of tumor volumes (control vs. $C D D P+E 3 C 1, p<0.05 ; C D D P$ vs. $C D D P+E 3 C 1, p<0.05)$. (F) After 11 days of treatment, comparison of mouse weights (control vs. $C D D P, p<0.01$; control vs. $C D D P+E 3 C 1, p<0.05 ; C D D P$ vs. $C D D P+E 3 C 1, p<0.01)$. Results are expressed as mean $\pm S D(E, F)$.

once a week. All 20 mice (control group, $n=7$; CDDP group, $n=6$; $\mathrm{CDDP}+\mathrm{E} 3 \mathrm{C} 1$ group, $n=7$ ) were euthanized because the tumor grew to $>5,000 \mathrm{~mm}^{3}$. Mice in the control group began to die from day 11 , and all mice treated in this group died by day 25 (Figure 1A). Mice treated by CDDP began to die from day 18 and all mice treated in this group died by day 29 (Figure 1A). In contrast, mice treated by CDDP+E3C1 began to die from day 22 and all mice treated in this group died by day 36 (Figure 1A). Survival rates of mice treated by CDDP or CDDP+E3C1 were significantly higher than the survival rate of mice in the control group (control vs. CDDP, $p=0.049$; control $v s$. CDDP+E3C $1, p=0.009$ ). In addition, the survival rate was significantly higher for mice of treated by $\mathrm{CDDP}+\mathrm{E} 3 \mathrm{C} 1$ than for mice treated by CDDP $(p=0.048)$. 
A

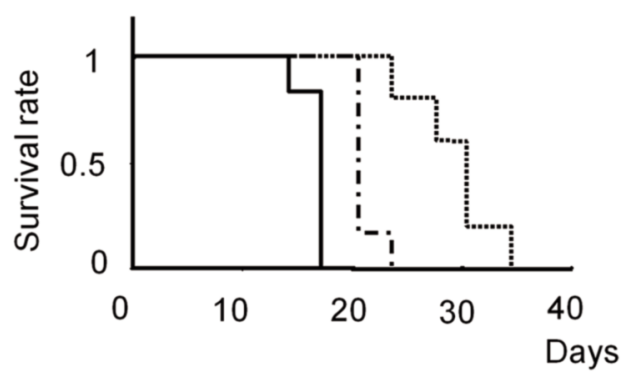

C

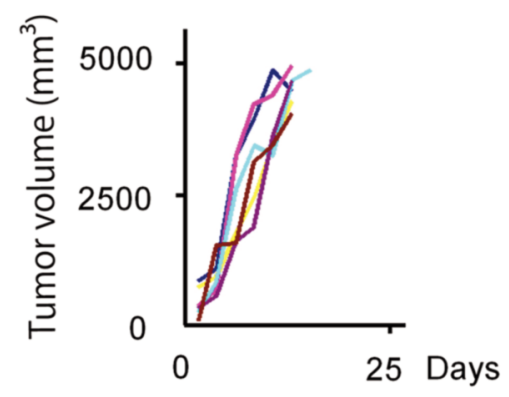

E

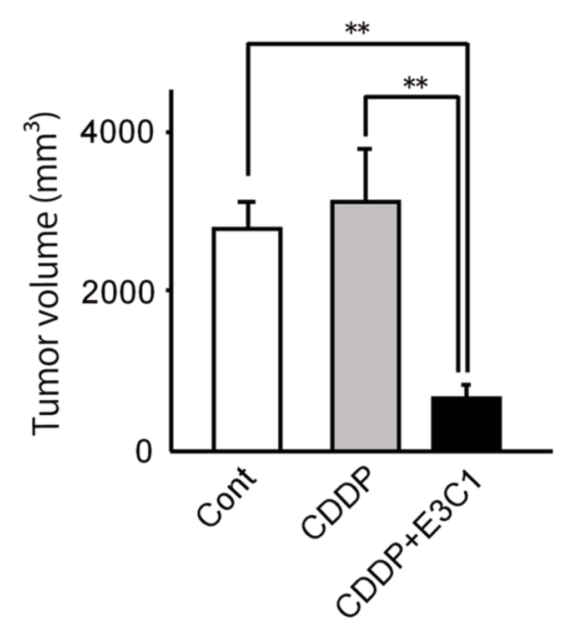

B

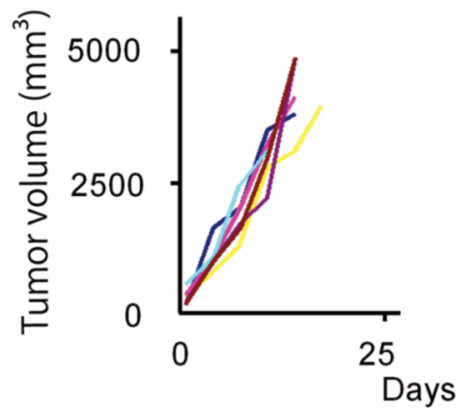

D

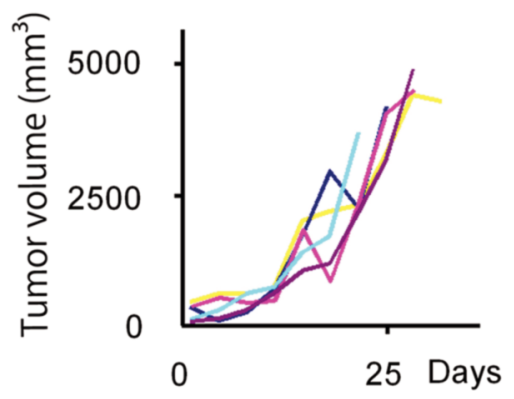

F

Figure 3. Effect of combination therapy for mice with transplanted SCC4 cells. (A) Kaplan-Meier survival curves of mice in the control group (solid line, $n=6), C D D P$ treatment group (chain line, $n=6)$ and CDDP $+E 3 C 1$ treatment group (dashed line, $n=5)(C o n t r o l v s . C D D P, p<0.01 ; C o n t r o l$ vs. $C D D P+E 3 C 1, p<0.01 ; C D D P$ vs. $C D D P+E 3 C 1, p<0.01)$. (B-D) Chronological changes in tumor volume in individual mice following control (B), $C D D P$ treatment $(C)$ and $C D D P+E 3 C 1$ treatment $(D)$. (E) After 11 days of treatment, comparison of tumor volumes $($ control vs. $C D D P+E 3 C 1, p<0.01$; $C D D P$ vs. $C D D P+E 3 C 1, p<0.01)$. (F) After 11 days of treatment, comparison of mouse weights. Results are expressed as mean \pm SD (E, $F)$.

Transplanted tumors in mice treated by control consistently increased in volume over time (Figure 1B). The rate of increase in tumor volume was slower in mice treated by CDDP than in control mice. However, the tumor volume of mice treated by CDDP also increased over time (Figure 1C). The rate of increase in tumor volume was the slowest in mice treated by CDDP+E3C1, and 6 out of 7 tumors showed temporary reductions in volume (Figure 1D). Mean tumor volume on day 11 of treatment was $3,149.071 \pm 1,139.171$ $\mathrm{mm}^{3}$ in control mice, $1,843.583 \pm 556.3021 \mathrm{~mm}^{3}$ in mice treated by CDDP and $1514.071 \pm 471.3341 \mathrm{~mm}^{3}$ in mice treated by $\mathrm{CDDP}+\mathrm{E} 3 \mathrm{C} 1$ (control vs. CDDP, $p=0.035$; control vs. $\mathrm{CDDP}+\mathrm{E} 3 \mathrm{C} 1, \quad p=0.009 ; \mathrm{CDDP}$ vs. CDDP+E3C1, $p=0.284$ ) (Figure 1E). In addition, mean body weights of 

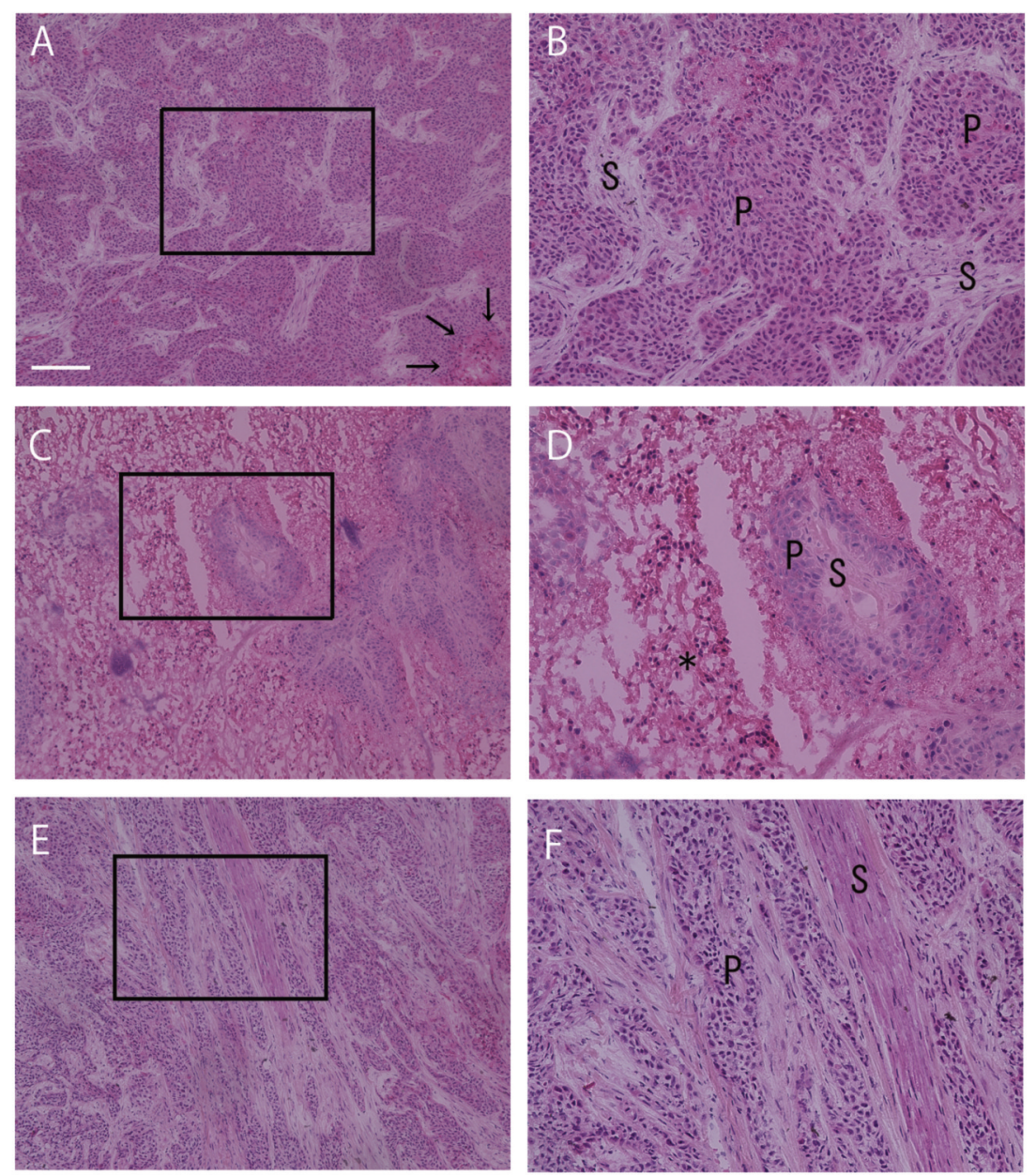

Figure 4. Histopathological analysis of mouse tumors by combination therapy. After 11 days of treatment, transplanted tumors were stained with hematoxylin and eosin in the control group $(A, B), C D D P$ treatment group $(C, D)$ and $C D D P+E 3 C 1$ treatment group $(E, F)$. (A, $C, E)$ Images were taken using a $\times 10$ objective lens. (A) Arrows indicate necrotic lesions. $(B, D, F)$ Enlargements of regions outlined in (A), (C) and (E), respectively (×20). Scale bars, $50 \mu \mathrm{m}$. P: parenchyma; $S$ : stroma; *cell death region.

mice on day 11 of treatment were $16.942 \pm 1.919 \mathrm{~g}$ in control mice, $16.547 \pm 2.773 \mathrm{~g}$ in mice treated by CDDP and $17.4 \pm 2.238 \mathrm{~g}$ in mice treated by CDDP+E3C1 (control vs. CDDP, $p=0.394$; control vs. CDDP+E3C1, $p=0.384$; CDDP vs. $\mathrm{CDDP}+\mathrm{E} 3 \mathrm{C} 1, p=0.356$ ) (Figure 1F).

Combination therapy with $C D D P+E 3 C 1$ prolonged survival in mice with SCCKN-derived tumors. Mice with tumors from SCCKN cells were treated by control, CDDP, or CDDP+E3C1 once a week. All 12 mice (control group, $n=4$; CDDP group, $n=4$; CDDP+E3C1 group, $n=4$ ) were euthanized because tumors grew to $>5,000 \mathrm{~mm}^{3}$. Mice in the control group began to die on day 11 and all mice died by day 18 (Figure 2A). On the other hand, mice treated by CDDP began to die on day 22 and all mice died by day 25 (Figure 2A). Mice treated by $\mathrm{CDDP}+\mathrm{E} 3 \mathrm{C} 1$ began to die on day 32 and all mice died by day
39 (Figure 2A). The survival rates of mice treated by CDDP or $\mathrm{CDDP}+\mathrm{E} 3 \mathrm{C} 1$ were significantly higher compared to control mice (control vs. CDDP, $p=0.035$; control vs. CDDP+E3C1, $p=0.023)$. In addition, the survival rate of mice treated by $\mathrm{CDDP}+\mathrm{E} 3 \mathrm{C} 1$ was significantly higher than that of mice treated by CDDP alone $(p=0.031)$. Transplanted tumors in control mice consistently increased in volume over time (Figure $2 \mathrm{~B}$ ). The rate of increase in tumor volume for mice treated by CDDP was slower compared to control mice. However, the tumor volume in mice treated by CDDP increased over time (Figure 2C). Two of the four tumors temporarily showed a reduction in volume (Figure $2 \mathrm{C}$ ). The rate of increase in tumor volume in mice treated by $\mathrm{CDDP}+\mathrm{E} 3 \mathrm{C} 1$ was the slowest of the three groups. Three of the four tumors temporarily decreased in volume (Figure 2D). Mean tumor volume on day 11 of treatment was $3,990.625 \pm 1,403.377 \mathrm{~mm}^{3}$ in mice treated with 
control, $3,468.375 \pm 757.457 \mathrm{~mm}^{3}$ in mice treated by CDDP and $1,177.875 \pm 481.35 \mathrm{~mm}^{3}$ in mice treated by CDDP+E3C1 (control vs. CDDP, $p=0.539$; control vs. CDDP+E3C1, $p=0.045$; CDDP vs. CDDP+E3C1, $p=0.041$ ) (Figure 2E). In addition, the mean weight of mice on day 11 of treatment was $17.809 \pm 0.948 \mathrm{~g}$ in mice treated by control, $13.282 \pm 0.589 \mathrm{~g}$ in mice treated by CDDP and $15.697 \pm 1.365 \mathrm{~g}$ in mice treated by $\mathrm{CDDP}+\mathrm{E} 3 \mathrm{C} 1$ (control vs. CDDP, $p=0.0003$; control $v s$. $\mathrm{CDDP}+\mathrm{E} 3 \mathrm{C} 1, p=0.042$; CDDP $v s . \mathrm{CDDP}+\mathrm{E} 3 \mathrm{C} 1, p=0.009)$ (Figure 2F).

Combination therapy with $C D D P+E 3 C 1$ prolonged survival in mice with SCC4-derived tumors. Mice with tumors from SCC4 cells were treated by control, CDDP, or CDDP+E3C1 once a week. All 17 mice (control group, $n=6$; CDDP group, $n=6$; CDDP+E3C1 group, $n=5$ ) were euthanized because the tumor grew to $>5,000 \mathrm{~mm}^{3}$. Mice in the control group began to die from day 15 and all mice died by day 18 (Figure 3A). Mice treated by CDDP began to die from day 22 and all mice died by day 25 (Figure 3A). Mice treated by CDDP+E3C1 began to die from day 25 and all died by day 36 (Figure $3 \mathrm{~A}$ ). The survival rates of mice treated by CDDP or CDDP+E3C1 were significantly higher compared to controls (control vs. CDDP, $p=0.009$; control $v s$. CDDP+E3C $1, p=0.008)$. In addition, the survival rate of mice treated by $\mathrm{CDDP}+\mathrm{E} 3 \mathrm{C} 1$ was significantly higher than that of mice treated by CDDP $(p=0.009)$. Transplanted tumors in mice treated by control showed consistent increases in tumor volume over time (Figure 3B). The rate of increase in tumor volume was slower for mice treated by CDDP compared to controls (Figure 3C). However, two of the six tumors showed temporary reductions in volume (Figure 3C). The rate of increase in tumor volume in mice treated by $\mathrm{CDDP}+\mathrm{E} 3 \mathrm{C} 1$ was the slowest of the three groups. Three out of five tumors showed temporary reductions in volume (Figure 3D). Mean tumor volume on day 11 of treatment was $2,702 \pm 394.405 \mathrm{~mm}^{3}$ in control mice treated, $3,135.5 \pm 870.581 \mathrm{~mm}^{3}$ in mice treated by CDDP and $619.1 \pm 105.532 \mathrm{~mm}^{3}$ in mice treated by CDDP+E3C1 (control vs. CDDP, $p=0.982$; control vs. CDDP+E3C1, $p=0.009$; CDDP $v s$. CDDP+E3C1, $p=0.008$ ) (Figure 3E). In addition, the mean weight of mice on day 11 of treatment was $18.115 \pm 1.944 \mathrm{~g}$ in control mice, $17.048 \pm 2.78 \mathrm{~g}$ in mice treated by CDDP and $18.721 \pm 1.484 \mathrm{~g}$ in mice treated by $\mathrm{CDDP}+\mathrm{E} 3 \mathrm{C} 1$ (control vs. CDDP, $p=0.453$; control vs. $\mathrm{CDDP}+\mathrm{E} 3 \mathrm{C} 1, p=0.39$; CDDP $v s . \mathrm{CDDP}+\mathrm{E} 3 \mathrm{C} 1, p=0.255$ ) (Figure 3F).

Combination therapy showed histopathological effects in transplanted tumors. Sections from transplanted tumors of SCC4 on day 11 of treatment were stained with hematoxylin and eosin for observation (Figure 4A-F). Tumors from control mice showed parenchyma and stroma, with little cell death (Figure 4A). Some sites of cell death were apparent
(Figure 4A arrow). Tumor stroma had developed (Figure 4B). By contrast, tumors treated by CDDP showed cell death in many parts of the tumor parenchyma and stroma (Figure 4C). Parenchyma was observed around the stroma (Figure 4D). Furthermore, parenchyma and stroma were neatly arranged in tumors treated by CDDP+E3C1 (Figure 4E). In addition, compared to tumors in the control or CDDP groups, the stroma was arranged regularly in a characteristic direction (Figure 4F).

Combination therapy resulted in improvement in the stroma of transplanted tumors. Next, mice with SCC4-derived tumors received intravenous injection of LEL via the caudal vein on day 11. Sections from the tumors were stained with antiaSMA. In control mice, anti-aSMA-positive cells were identified throughout the entire tumor stroma (Figure 5B). In addition, aSMA expression (Figure 5C) was found in the periphery of vessels filled by LEL (Figure 5A). In contrast, tumors in mice treated by CDDP showed lower expression of aSMA in the tumor stroma (Figure 5E), and little aSMA expression (Figure 5F) around vessels filled by LEL (Figure 5D). Tumors in mice treated by CDDP+E3C1 showed suppression of aSMA expression (Figure $5 \mathrm{H}$ ). Furthermore, aSMA expression (Figure 5I) was also suppressed around vessels filled by LEL (Figure 5G). The fluorescent intensity of aSMA was $1 \pm 0.12$ in the control group, compared to $0.32 \pm 0.01$ in the CDDP group and $0.25 \pm 0.03$ in the $\mathrm{CDDP}+\mathrm{E} 3 \mathrm{C} 1$ group (control vs. CDDP, $p=0.00006$; control vs. CDDP+E3C1, $p=0.00006$; CDDP vs. CDDP+E3C1, $p=0.007$ ) (Figure 5J).

Combination therapy caused transformation in tumor angiogenesis in the transplanted tumors. Mice with SCC4derived tumors received intravenous injections of Indian ink via the caudal vein on day 11 . In control mice, tumor vessels with numerous developing branches were observed (Figure 6A). In addition, a number of thin blood vessels were observed (Figure 6A). Tumor vessels were also reduced in number and branches, with no thick blood vessels observed in mice treated by CDDP (Figure 6B). On the other hand, thick blood vessels were seen following treatment by $\mathrm{CDDP}+\mathrm{E} 3 \mathrm{C} 1$ (Figure 6C). However, the number of thin vessels and branches was reduced compared to tumor vessels in mice treated by control (Figure 6C).

In addition, tumor sections were stained using PECAM as an endothelial cell marker. In tumors from mice treated by control, expression of PECAM was observed in the tumor stroma (Figure 7A-C). Expression of PECAM in the stroma was also observed after treatment with CDDP, but the expression rate was lower than that in control mice (Figure 7D-F). On the other hand, tumors in mice treated by $\mathrm{CDDP}+\mathrm{E} 3 \mathrm{C} 1$ showed expression of PECAM in the tumor stroma similar to that of controls (Figure 7G-I). In addition, vascularization was evident in the stroma [Figure 7G (arrow)]. 
LEL
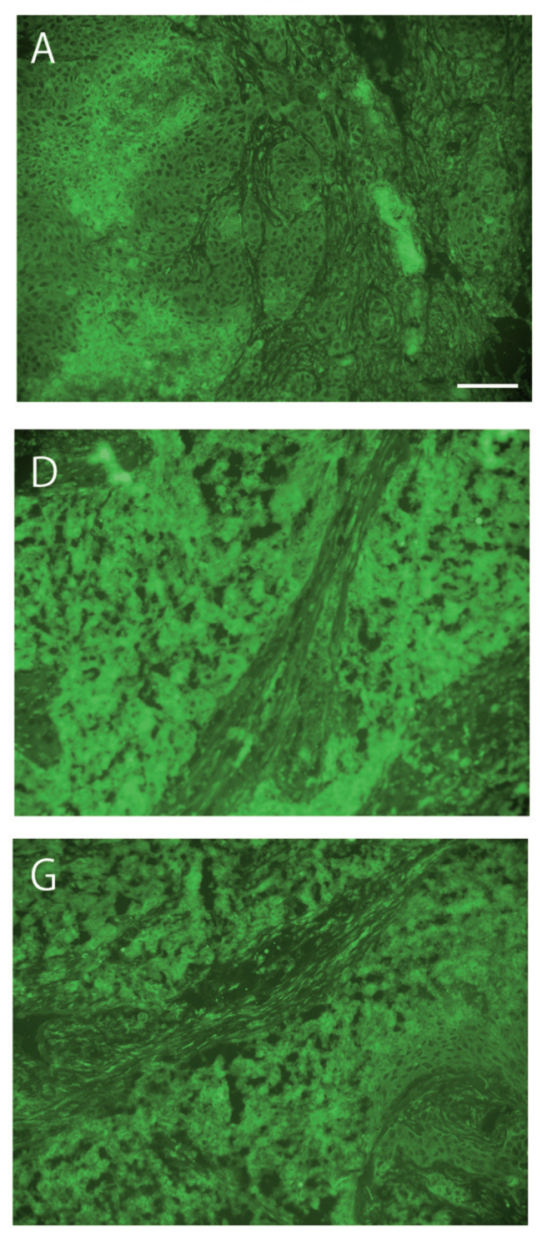

J

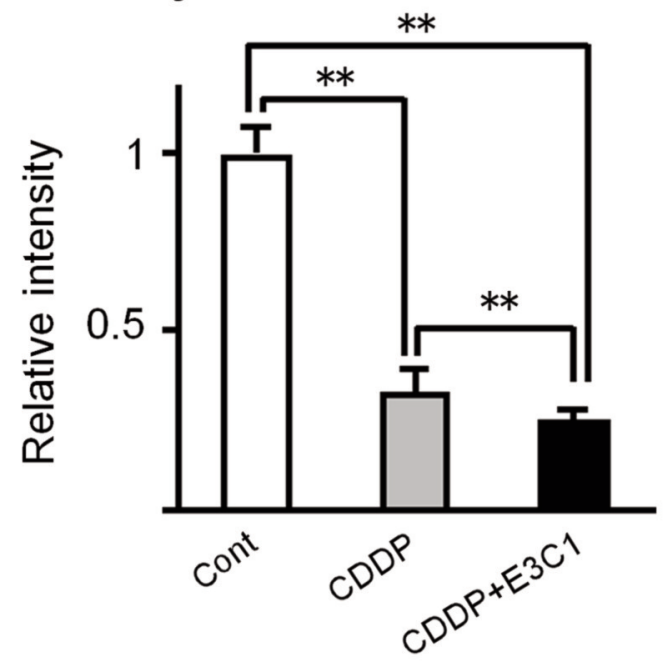

aSMA
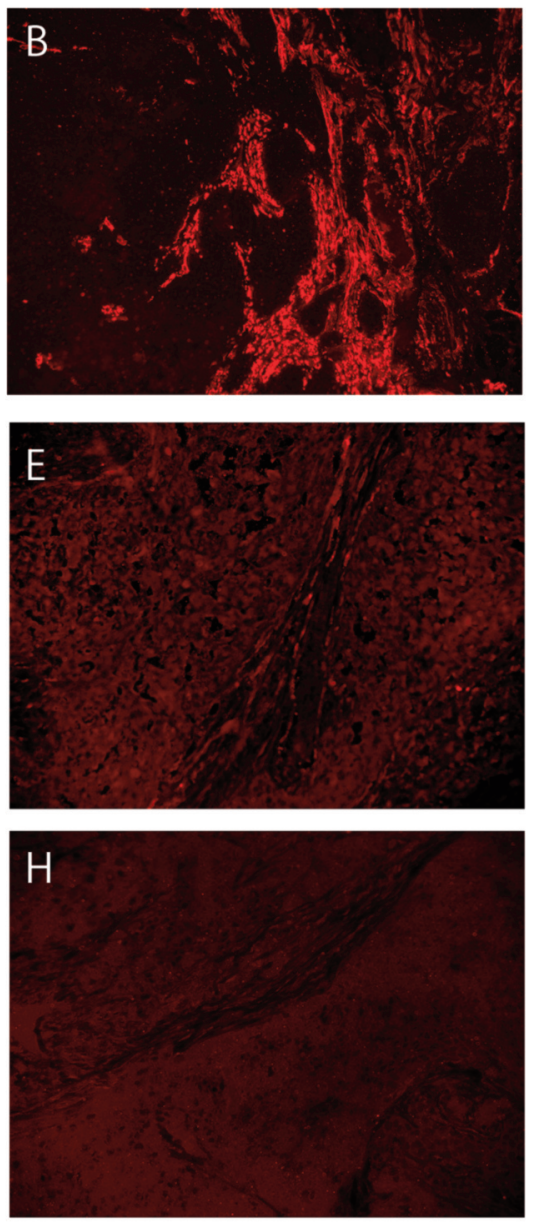

\section{Merged}
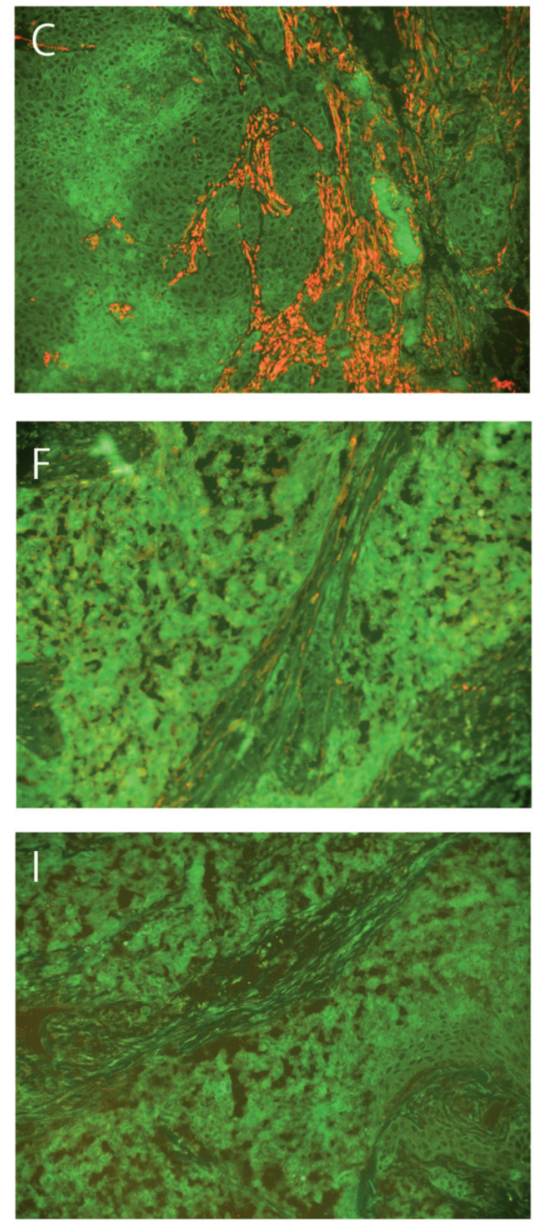

Figure 5. Immunohistochemistry analysis of mouse transplanted tumor by combination therapy. After 11 days of treatment, mice with transplanted tumors were injected with Lycopersicon esculentum lectin (LEL) after each treatment (green). Specimens of transplanted tumors from mice were stained by immunohistochemistry using anti-aSMA antibody (Red). Control (A-C), CDDP treatment group (D-F), CDDP $+E 3 C 1$ treatment group $(G-I)$. Magnification is $\times 20$. Scale bars correspond to $50 \mu \mathrm{m}$. The ratio for the control was taken as 1 (control vs. CDDP, $p<0.01 ;$ control vs. $C D D P+E 3 C 1, p<0.01 ; C D D P$ vs. $C D D P+E 3 C 1, p<0.01)$. Results are expressed as mean $\pm S D(J)$. 

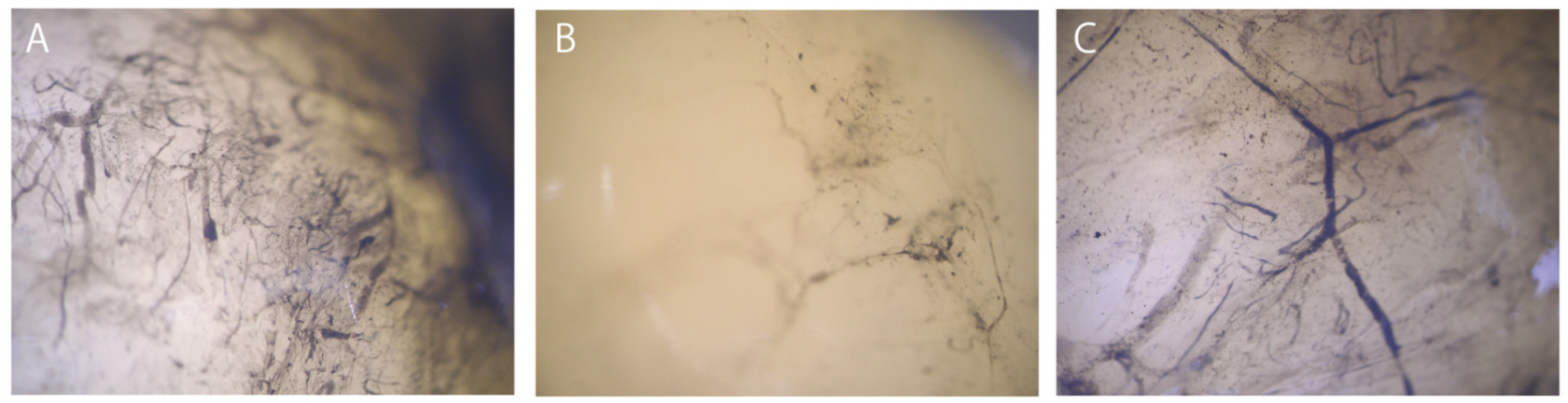

Figure 6. Tumor angiogenesis analysis of mouse transplanted tumor by combination therapy on angiography. After 11 days of treatment, mice with transplanted tumors were injected with India ink after each treatment. Control group $(A), C D D P$ treatment group $(B)$ and CDDP $+E 3 C 1$ treatment group $(C)$. Scale bars, $50 \mu \mathrm{m}$.

\section{Discussion}

Currently, chemotherapy with CDDP, bleomycin, and methotrexate is effective in the treatment of SCC, and polypharmacy, including CDDP, has been reported to have a high response $(42,43)$. Kitano et al. reported that cancer gene therapy with the $\mathrm{E} 3 \mathrm{C} 1$ domain of Del1 was effective in the treatment of SCC $(28,29)$. In this study, chemotherapy with $\mathrm{CDDP}$ and cancer gene therapy with $\mathrm{E} 3 \mathrm{C} 1$ for mice that had received transplants of SCC was conducted to determine the therapeutic effects. The carcinoma cell lines used for transplantation into mice were human epidermoid SCC cells (A431), human oral SCC cells (SCCKN) and human oral SCC cells (SCC4). Treatment of A431, SCCKN, and SCC4-derived tumors with CDDP reduced tumor growth rates compared to controls. Survival was extended by 4 days in the case of A431, 7 days in SCCKN and 7 days in SCC4, compared to controls. In addition, treatment with $\mathrm{CDDP}+\mathrm{E} 3 \mathrm{C} 1$ further reduced the rate of tumor growth compared to the treatment with CDDP. Survival was extended by 7 days for A431, 14 days for SCCKN, and 9 days for SCC4, compared to treatment with CDDP alone. These results show that the combination of $\mathrm{CDDP}+\mathrm{E} 3 \mathrm{C} 1$ is much more effective in suppressing tumor growth and improving the survival of mice with transplanted SCC cells, compared to CDDP treatment alone. In addition, on day 11 of treatment, comparison of mouse body weights showed that mice treated with CDDP had lost more weight than the control, but those treated by CDDP $+\mathrm{E} 3 \mathrm{C} 1$ had gained weight compared to controls. This result suggested that $\mathrm{E} 3 \mathrm{C} 1$ suppressed the problematic side effects (weight reduction) of treatment by CDDP. The addition of E3C1 morphologically normalized the development of stroma and vessels. Suppression of weight reduction could be through $\mathrm{E} 3 \mathrm{C} 1$ that might improve metabolism in stroma against the adverse effects of CDDP. However, the mechanisms involved remain unclear.

Next, analyses were conducted to clarify the reasons behind the greater effectiveness of combined CDDP and
E3C1 treatment, compared to CDDP treatment alone, in suppressing tumor growth. In observation of the tumor on day 11 of treatment, the treatment by CDDP showed cell death in many parts of the tumor parenchyma and stroma, while stroma in the remaining parts of the tumor was underdeveloped. On the other hand, stroma in the remaining part of the tumor was more developed in the CDDP $+\mathrm{E} 3 \mathrm{C} 1$ group compared to controls. The primary purpose of cancer chemotherapy is to kill cancer cells by acting directly on the tumor parenchyma. Histological evaluation of the effect of chemotherapy has thus been focusing on changes in cancer parenchyma, such as degeneration and necrosis of cancer cells (44). However, more recently, the stroma of cancer tumors has received increased attention, as the extracellular matrix has been actively studied and its biological significance debated $(45,46)$. Tissue specimens have been observed in detail, showing that treatment by CDDP causes degeneration and necrosis not only in the cancer parenchyma, but also in the interstitial space around the oncocyst. However, stromal development was observed in mice treated by $\mathrm{CDDP} \mathrm{E} 3 \mathrm{C} 1$, suggesting that $\mathrm{E} 3 \mathrm{C} 1$ repaired or altered the CDDP-denatured stroma.

Stromal cells in tumors are closely related to cancer growth and metastasis by producing cell-to-cell contacts and various extracellular matrix proteins (47-49). Stromal cells include fibroblasts, vascular endothelial cells, antigenpresenting cells, innate immune cells, and acquired immune cells. In cancer, the stroma reportedly maintains an active phenotype and establishes a favorable microenvironment for cancer progression through promotion of cancer cell proliferation, angiogenesis, vascular invasion by cancer cells and control of the immune response (50). In addition, stromal factors reportedly correlate with prognosis in different cancers including head and neck, lung, colon cancer and others (51-53). Denatured stroma from the combination treatment with $\mathrm{CDDP}+\mathrm{E} 3 \mathrm{C} 1$ was thus considered to have affected the growth and angiogenesis of cancer cells. 
PECAM
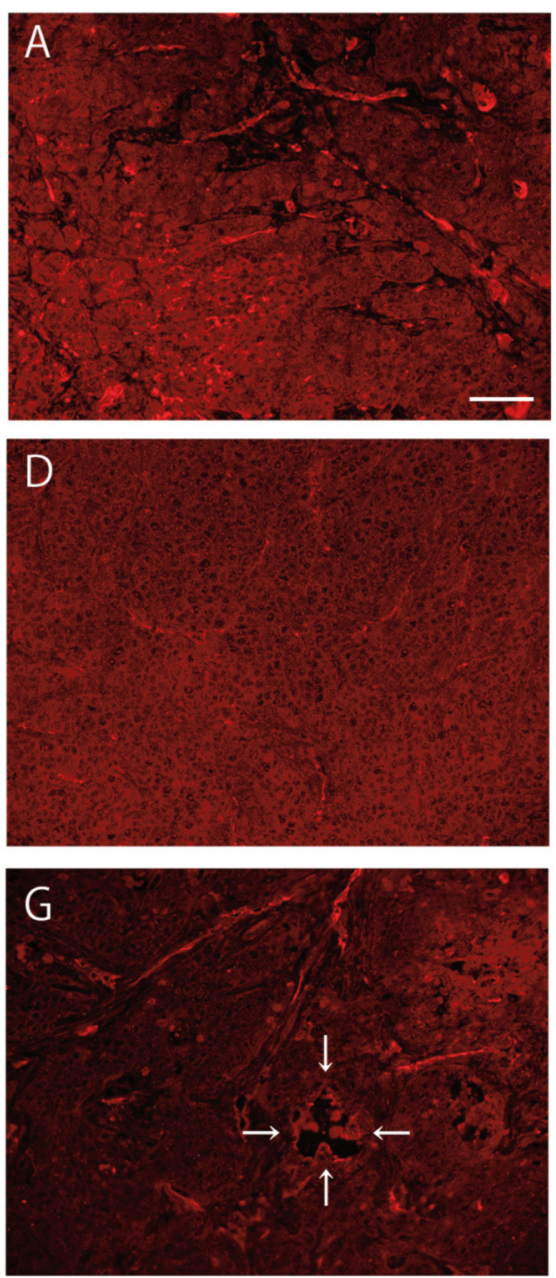

Hoechst
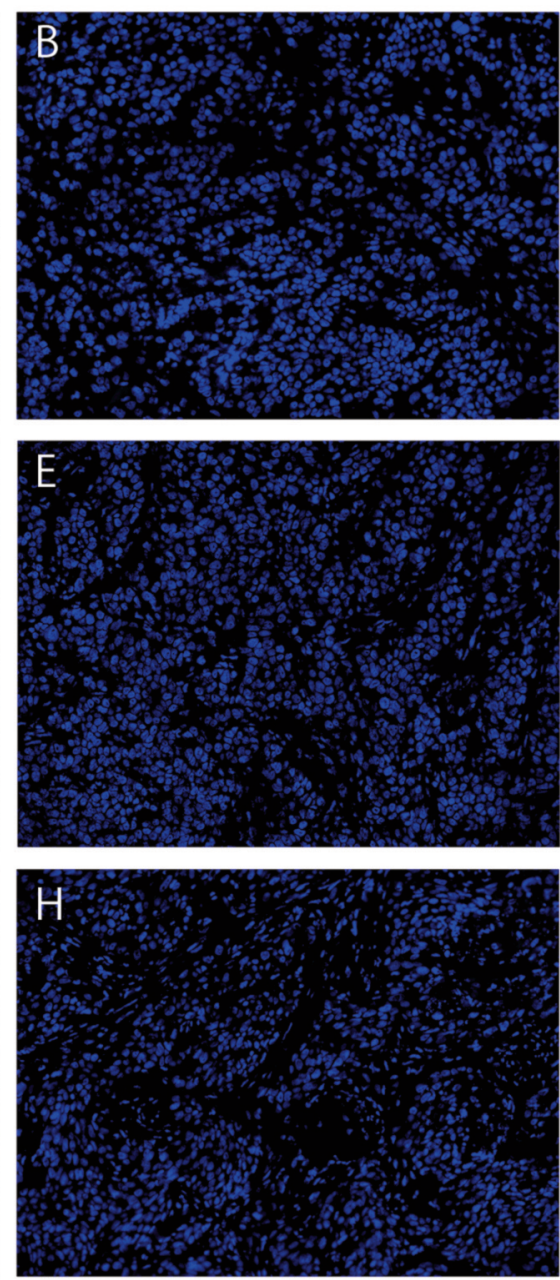

Merged
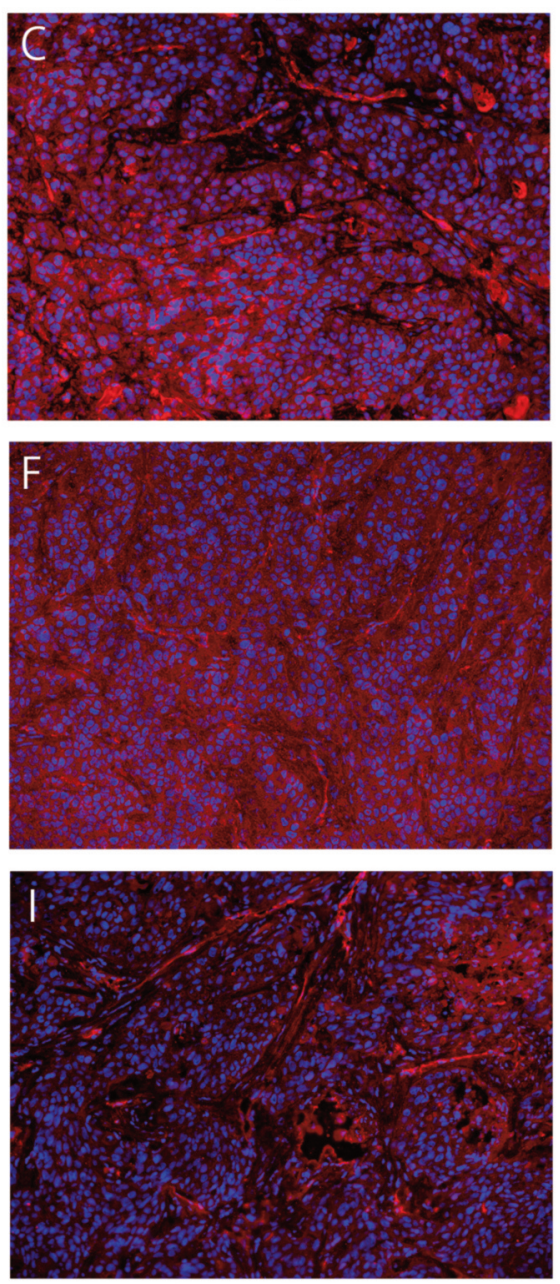

Figure 7. Immunohistochemical analysis of tumor angiogenesis of mouse tumors with combination therapy. After 11 days of treatment, the tumor specimen was stained using an anti-PECAM antibody (red) and Hoechst33342 (blue). Control group (A-C), CDDP treatment group (D-F), $C D D P+E 3 C 1$ treatment group $(G-I)$. Arrows indicate vascular lumen $(G)$. Magnification is $\times 20$. Scale bars correspond to $50 \mu m$.

Typically, angiogenesis occurs in the peritumoral area as the tumor increases in size. Necrosis of tumor cells due to blood flow arrest is repeated inside the tumor $(54,55)$. Fujisawa (56) reported how CDDP affects angiogenesis in cancer, but details of the association between CDDP and angiogenesis have not been clarified. In our study, the cancer stroma degenerated with treatment using CDDP. Vascular endothelial cells were considered to have been damaged by CDDP treatment and angiogenesis was reduced. Tumor vessels present in the stroma of each treatment group were thus observed. Fewer tumor vessels were seen in the group treated by CDDP compared to control. In addition, tumor vessels in the CDDP group were less well developed than in controls. This suggests that CDDP treatment caused degeneration and necrosis of the tumor stroma, resulting in the destruction of blood vessels. On the other hand, $\mathrm{CDDP}+\mathrm{E} 3 \mathrm{C} 1$ tumor vessels were thicker and more developed, with numerous vascular branches. In addition, stromal degeneration attributed to CDDP treatment was restored and redeveloped by the effect of $\mathrm{E} 3 \mathrm{C} 1$. Angiogenesis was thus was thought to be accelerated. In short, vessel transfer and distribution with stromal development were observed in each treatment group. However, the results appear inexplicable and contradictory given the reduced tumor growth rate and prolonged life expectancy of mice treated by CDDP $+\mathrm{E} 3 \mathrm{C} 1$.

The relationship between tumor vessels and tumor stroma in each treatment group was therefore examined by immunostaining for aSMA, an actin stress fiber formed in cells during fibroblast activation. This protein plays an important role in the formation of cell motility and is widely used as a marker of cancer stroma $(57,58)$. In head and neck, 
lung, colon and various other cancers, aSMA expression has been reported to correlate with prognosis $(53,59-61)$. Expression of aSMA was somewhat suppressed by CDDP treatment, but CDDP+E3C1 treatment completely suppressed aSMA expression. In addition, tumors were immunostained with PECAM, a marker for vascular endothelial cells, and angiogenesis was examined. Angiogenesis and proliferation were both seen to be inhibited in by CDDP treatment, whereas treatment by $\mathrm{CDDP}+\mathrm{E} 3 \mathrm{C} 1$ showed significant angiogenesis and proliferation. This result was reviewed in conjunction with the results for aSMA and H-E staining. The stroma that developed under CDDP+E3C1 treatment was considered to represent normal tissue stroma instead of cancer stroma. The angiogenesis seen with $\mathrm{CDDP}+\mathrm{E} 3 \mathrm{C} 1$ treatment would thus reflect that in normal tissues.

These results were considered to indicate that $\mathrm{E} 3 \mathrm{C} 1$ restores or alters the CDDP-degenerated interstitium, but the altered interstitium represents normal tissue interstitium and is thus recruited to tumor control. Currently, the stroma of carcinoma is considered to play a very important role in the process of SCC invasion into surrounding tissues $(62,63)$. In normal tissues, the stroma remains homeostatic. However, cancer stroma promotes invasion of cancer cells and angiogenesis $(64,65)$. In this study, the cancer stroma altered by $\mathrm{CDDP}+\mathrm{E} 3 \mathrm{C} 1$ treatment was well-developed and there was active angiogenesis and proliferation. However, the stroma altered by E3C1 was not repaired as cancerous interstitium, but instead was transformed into normal tissue stroma with the function of maintaining homeostasis. These findings suggest that the tumor growth rate was controlled and mice transplanted with tumors achieved an extended survived. The stroma of cancers treated with E3C1 should thus be investigated in more detail in the future.

\section{Conclusion}

In SCC, CDDP+E3C1 treatment was more effective than CDDP treatment alone for inhibiting tumor growth and prolonging survival. $\mathrm{CDDP}+\mathrm{E} 3 \mathrm{C} 1$ treatment was considered to transform the cancer stroma back into normal stroma. In addition, E3C1+CDDP treatment prevented the side effects (weight reduction) of CDDP treatment.

\section{Conflicts of Interest}

There Authors have no conflicts of interest to declare.

\section{Authors' Contributions}

Hisataka Kitano, You Masaoka, and Yusuke Fujiwara performed the research; Hisataka Kitano and Chiaki Hidai designed the research study; Hisataka Kitano, You Masaoka, Atsushi Mamiya, and Toshio Miki contributed essential reagents or tools; Hisataka Kitano and Chiaki Hidai wrote the paper.

\section{Acknowledgements}

This work was supported by a Grant-in-Aid for Scientific Research from the Ministry of Education and Culture of Japan (22792019).

\section{References}

1 Rosenberg B, Van Camp L and Krigas T: Inhibition of cell division in Escherichia coli by electrolysis products from a platinum electrode. Nature 205: 698-699, 1965. PMID: 14287410. DOI: $10.1038 / 205698 \mathrm{a} 0$

2 Rosenberg B, Van camp L, Trosko JE and Mansour VH: Platinum compounds: A new class of potent antitumor agents. Nature 222: 385-386, 1969. PMID: 5782119. DOI: 10.1038/222385a0

3 Lippert B: Cisplatin: Chemistry and biochemistry of leading anticancer drug. Weinheim, Wiley-VCH, pp 183-205, 1999.

4 Hay RW, Dilworth $J$ and Nolan KB: Perspectives on bioinorganic chemistry, Vol. 4, $1^{\text {st }}$ Edition. New Haven, JAI Press, 1999.

5 Berg JM and Lippard SJ: Principles of bioinorganic chemistry. Mill Valley, California, University Science Books, 1994.

6 Uemura $\mathrm{M}$ and Komeda S: The present and the future of platinum-based anticancer drugs. Biomed Res Trace Elem 26(4): 157-165, 2015. DOI: $10.11299 /$ brte. 26.157

7 Rosenberg B: Antitumor activity of cis-dich lorodiammineplatinum (II) and some relevant chemistry. Cancer Treat Rept 63: 1433-1438, 1979. PMID: 498145.

8 Zwelling LA and Kohn KW: Mechanism of action of cisdichlorodiammineplatinum (II). Cancer Treat Rept 63: 14391444, 1979. PMID: 387221.

9 Rosenberg B: Fundamental studies with cisplatin. Cnacer 55: 2303-2316, 1985. PMID: 3886121. DOI: 10.1002/1097-0142

10 Williams CJ and Whitehouse JMA: Cis-platinum: a new anticancer agent. British Medical_Journal 1: 1689-1691, 1979. PMID: 380759. DOI: 10.1136/bmj.1.6179.1689

11 Panettiere FJ, Lehane D, Fletcher WS, Stephens R, Rivkin S and McCracken JD: Cis-platinum therapy of previously treated head and neck cancer: the Southwest Oncology Group's two-dose-permonth outpatient regimen. Med Pediatr Oncol 8(3): 221-225, 1980. PMID: 7193277. DOI: 10.1002/mpo.2950080303

12 Cheung DK, Regan FJ, Savin M, Gibberman V and Woessner W: A pilot study of intraarterial chemotherapy with cisplatin in locally advanced head and neck cancer. Cancer 61: 903-908, 1988. PMID: 3338055. DOI: 10.1002/1097-0142

13 Mortimer JE, Taylor ME, Schulman S, Cummings C, Weymuller E Jr and Laramore G: Feasibility and efficacy of weekly intraarterial cisplatin in locally advanced (stage III and N) head and neck cancers. J Clin Oncol 6: 969-975, 1988. PMID: 3373266. DOI: 10.1200/JCO.1988.6.6.969

14 Spaulding MB, Klotch D, Grillo J, Sanani S and Loré JM: Adjuvant chemotherapy in the treatment of advanced tumors of the head and neck. Am J Surg 140: 538-542, 1980. PMID: 6158882. DOI: $10.1016 / 0002-9610(80) 90207-x$

15 Ervin TJ, Weichselbaum R, Miller D, Meshad M, Posner M and Fabian R: Treatment of advanced squamous cell carcinoma of the head and neck with cisplatin, bleomycin, and methotrexate (PBM). Cancer Treat Rep 65: 787-791, 1981. PMID: 6168371.

16 Soberero A and Bertino JR: Clinical aspects of drug resistance. Cancer Surv 5: 93-107, 1986. PMID: 3297314. 
17 Kuppen PJ, Schuitemaker H, van 't Veer LJ, de Bruijn EA, van Oosterom AT and Schrier PI: Cis-diamminedichloro-platinum (II) -resistant subline derived from two human ovarian tumor cell lines. Cancer Res 48: 3355-3359, 1988. PMID: 2897238.

18 Belehradek J and Paoletti J: Studies with cis-diamminedichloroplatinum (II)-resistant cultured tumor cells. Proc Am Assoc Cancer Res 26: 337-340, 1985.

19 Goldie, J. H. and Coldman, A. J: The geneticorigin of drug resistance in neoplasm: Implication for systemic therapy. Cancer Res 44: 3643-3653, 1984. PMID: 6744284.

20 Ozols RF: Pharmacologic reversal of drugresistance in ovarian cancer. Semin. Oncol 12: 7-11, 1985. PMID: 4048979.

21 Chan AT, Teo PM, Ngan RK, Leung TW, Lau WH, Zee B, Leung SF, Cheung FY, Yeo W, Yiu HH, Yu KH, Chiu KW, Chan DT, Mok T, Yuen KT, Mo F, Lai M, Kwan WH, Choi P and Johnson PJ: Concurrent chemotherapy-radiotherapy compared with radiotherapy alone in locoregionally advanced nasopharyngeal carcinoma: progression-free survival analysis of a phase III randomized trial. J Clin Oncol 20(8): 2038-2044, 2002. PMID: 11956263 . DOI: $10.1200 / J C O .2002 .08 .149$

22 Kwong DL, Sham JS, Au GK, Chua DT, Kwong PW, Cheng AC, Wu PM, Law MW, Kwok CC, Yau CC, Wan KY, Chan RT and Choy DD: Concurrent and adjuvant chemotherapy for nasopharyngeal carcinoma: a factorial study. J Clin Oncol 22(13): 2643-2653, 2004. PMID: 15226332. DOI: 10.1200/ JCO.2004.05.173

23 Wee J, Tan EH, Tai BC, Wong HB, Leong SS, Tan T, Chua ET, Yang E, Lee KM, Fong KW, Tan HS, Lee KS, Loong S, Sethi V, Chua EJ and Machin D: Randomized trial of radiotherapy versu s concurrent chemoradiotherapy followed by adjuvant chemotherapy in patients with American Joint Committee on Cancer/International Union against cancer stage III and IV nasopharyngeal cancer of the endemic variety. J Clin Oncol 23(27): 6730-678, 2005. PMID: 16170180. DOI: 10.1200/ JCO.2005.16.790

24 Lee AW, Tung SY, Ngan RK, Chappell R, Chua DT, Lu TX, Siu L, Tan T, Chan LK, Ng WT, Leung TW, Fu YT, Au GK, Zhao C, O'Sullivan B, Tan EH and Lau WH: Factors contributing to the efficacy of concurrent-adjuvant chemotherapy for locoregionally advanced nasopharyngeal carcinoma: combined analyses of NPC9901 and NPC-9902 Trials Eur J Cancer 47(5): 656-666, 2011. PMID: 21112774. DOI: 10.1016/j.ejca.2010.10.026

25 Adelstein D, Gillison ML, Pfister DG, Spencer S, Adkins D, Brizel DM, Burtness B, Busse PM, Caudell JJ, Cmelak AJ, Colevas AD, Eisele DW, Fenton M, Foote RL, Gilbert J, Haddad RI, Hicks WL, Hitchcock YJ, Jimeno A, Leizman D, Lydiatt WM, Maghami E, Mell LK, Mittal BB, Pinto HA, Ridge JA, Rocco J, Rodriguez CP, Shah JP, Weber RS, Witek M, Worden F, Yom SS, Zhen W, Burns JL and Darlow SD: NCCN Guidelines Insights: Head and Neck Cancers, Version 2. 2017. J Natl Compr Canc Netw 15(6): 761-770, 2017. PMID: 28596256. DOI: $10.6004 /$ jncen.2017.0101

26 Culver K, Cornetta K, Morgan R, Morecki S, Aebersold P, Kasid A, Lotze M, Rosenberg SA, Anderson WF and Blaese RM: Lymphocytes as cellular vehicles for gene therapy in mouse and man. Proc Natl Acad Sci USA 88(8): 3155-3159, 1991. PMID: 2014235. DOI: $10.1073 /$ pnas.88.8.3155

27 Morecki S, Karson E, Cornetta K, Kasid A, Aebersold P, Blaese RM, Anderson WF and Rosenberg SA: Retrovirus-mediated gene transfer into CD4+ and CD8+ human $\mathrm{T}$ cell subsets derived from tumor-infiltrating lymphocytes and peripheral blood mononuclear cells. Cancer Immunol Immunother 32(6): 342352, 1991. PMID: 2007247. DOI: 10.1007/BF01741329

28 Kitano H, Mamiya A and Hidai C: Improvement of FasL gene therapy in vitro by fusing the FasL to Del1 protein domains. In: Targets in Gene Therapy. Yong P, Rijeka Y (eds.). Croatia, InTech., pp 147-158, 2011.

29 Kitano H, Mamiya A, Kokubun S and Hidai C: Efficient nonviral gene therapy with FasL and Del1 fragments in mice. J Gene Med 14(11): 642-650, 2012. PMID: 23136083. DOI: $10.1002 / j g m .2682$

30 Hidai C, Zupancic T, Penta K, Mikhail A, Kawana M, Quertermous EE, Aoka Y, Fukagawa M, Matsui Y, Platika D, Auerbach R, Hogan BL, Snodgrass R and Quertermous T: Cloning and characterization of developmental endothelial locus1: an embryonic endothelial cell protein that binds the alphavbeta3 integrin receptor. Genes Dev 12(1): 21-33, 1998. PMID: 9420328. DOI: 10.1101/gad.12.1.21

31 Kitano H, Hidai C, Kawana M and Kokubun S: An epidermal growth factor-like repeat of Del1 protein increases the efficiency of gene transfer in vitro. Mol Biotechnol 39(3): 179-185, 2008. PMID: 18322824. DOI: 10.1007/s12033-008-9038-7

32 Mamiya A, Kitano H, Takao K, Kokubun S, Komiya M and Hidai C: An epidermal growth factor motif from Dell protein increases the efficiency of in vivo gene transfer with a non-viral vector. Mol Biotechnol 54: 445-450, 2013. PMID: 22782704. DOI: $10.1007 / \mathrm{s} 12033-012-9582-\mathrm{z}$

33 Hidai C, Kawana M, Kitano H and Kokubun S: Discoidin domain of Dell protein contributes to its deposition in the extracellular matrix. Cell Tissue Res 330(1): 83-95, 2007. PMID: 17701220. DOI: 10.1007/s00441-007-0456-9

34 Kitano H, Mamiya A, Ishikawa T, Egoshi K, Kokubun S and Hidai C: Long-term gene therapy with del1 fragment using nonviral vectors in mice with explanted tumors. OncoTargets Ther 9: 503-516, 2016. PMID: 26889088. DOI: 10.2147/OTT.S90801

35 Kitano H, Ishikawa T, Tamura E, Kokubun S and Hidai C: Efficient cancer gene therapy with a Del1 fragment administered by hypodermic injection in a mouse explanted tumor model. Transl Cancer Res 3: 686-694, 2018. DOI: 10.21037/tcr. 2018.05.45

36 Giard DJ, Aaronson SA, Todaro GJ, Arnstein P, Kersey JH, Dosik $\mathrm{H}$ and Parks WP: In vitro cultivation of human tumors: establishment of cell lines derived from a series of solid tumors. J Natl Cancer Inst 51: 1417-1423, 1973. PMID: 4357758. DOI: $10.1093 /$ jnci/51.5.1417

37 Faust JB and Meeker TC: Amplification and expression of the bcl-1 gene in human solid tumor cell lines. Cancer Res 52: 24602463, 1992. PMID: 1568216.

38 Urade M, Ogura T, Mima T and Matsuya T: Acquisition of bleomycin (BLM) resistance in human squamous cell carcinoma transplantable in nude mice. Cancer J 3: 192-196, 1990.

39 Urade M, Ogura T, Mima T and Matsuya T: Establishment of human squamous carcinoma cell lines highly and minimally sensitive to bleomycin and analysis of factors involved in the sensitivity. Cancer 69: 2589-2597, 1992. PMID: 1373668. DOI: 10.1002/1097-0142

40 Rheinwald JG and Beckett MA: Defective terminal differentiation in culture as a consistent and selectable character of malignant human keratinocytes. Cell 22: 629-632, 1980. PMID: 6160916. DOI: 10.1016/0092-8674(80)90373-6 
41 Rheinwald JG and Beckett MA: Tumorigenic keratinocyte lines requiring anchorage and fibroblast support cultures from human squamous cell carcinomas. Cancer Res 41: 1657-1663, 1981. PMID: 7214336.

42 Wittes RE, Cvitkovic E, Shah J, Gerold FP and Strong EW: Cisdichlorodiammineplatinum (II) in the treatment of epidermoid carcinoma of the head and neck. Cancer Treat Rept 61(3): 359366, 1977. PMID: 872136.

43 Wittes R, Heller K, Randolph V, Howard J, Vallejo A, Farr H, Harrold C, Gerold F, Shah J, Spiro R and Strong E: Cis dichlorodiammineplatinum (II) based chemotherapy as initial treatment of advanced head and neck cancer. Cancer Treat Rept 63: 1533-1538, 1979. PMID: 498153.

44 Shimosato Y, Oboshi S and Baba K: Histological evaluation of effects radiotherapy and chemotherapy for carcinomas. Jap J Clin Oncol 1: 19-35, 1971. DOI: 10.1093/oxfordjournals.jjco.a039343

45 Liotta LA, Rao CN and Barsky SH: Tumor invasion and the extracellular matrix. Lab Invest 49: 636-649, 1983. PMID: 6317982.

46 Barsky SH, Rao CN, Grotendorst GR and Liotta LA: Increased content of type $\mathrm{V}$ collagen in desmoplasia of human breast carcinoma. Am J Pathol 108: 276-283, 1983. PMID: 6287844.

47 Augsten M: Cancer-associated fibroblasts as another polarized cell type of the tumor microenvironment. Front Oncol 4: 62, 2014. PMID: 24734219 . DOI: $10.3389 /$ fonc. 2014.00062

48 Franco OE, Shaw AK, Strand DW and Hayward SW: Cancer associated fibroblasts in cancer pathogenesis. Semin Cell Dev Biol 21: 33-39, 2010. PMID: 19896548. DOI: 10.1016/j.semcdb. 2009.10.010

49 Kalluri R and Zeisberg M: Fibroblasts in cancer. Nat Rev Cancer 6: 392-401, 2006. PMID: 16572188. DOI: $10.1038 / \mathrm{nrc} 1877$

$50 \mathrm{Li} \mathrm{H}$, Fan X and Houghton J: Tumor microenvironment: the role of the tumor stroma in cancer. J Cell Biochem 101: 805-815, 2007. PMID: 17226777. DOI: 10.1002/jcb.21159

51 Bello IO, Vered M, Dayan D, Dobriyan A, Yahalom R, Alanen K, Nieminen P, Kantola S, Läärä E and Salo T: Cancerassociated fibroblasts, a parameter of the tumor microenvironment, overcomes carcinoma-associated parameters in the prognosis of patients with mobile tongue cancer. Oral Oncol 47: 33-38, 2011. PMID: 21112238. DOI: 10.1016/ j.oraloncology.2010.10.013

52 Ito M, Ishii G, Nagai K, Maeda R, Nakano Y and Ochiai A: Prognostic impact of cancer-associated stromal cells in patients with stage I lung adenocarcinoma. Chest 142: 151-158, 2012. PMID: 22302300. DOI: 10.1378/chest.11-2458

53 Herrera M, Herrera A, Domínguez G, Silva J, García V, García JM, Gómez I, Soldevilla B, Muñoz C, Provencio M, CamposMartin Y, García de Herreros A, Casal I, Bonilla F and Peña C: Cancer-associated fibroblast and M2 macrophage markers together predict outcome in colorectal cancer patients. Cancer Sci 104: 437-444, 2013. PMID: 23298232. DOI: 10.1111/cas.12096

54 Penfold NC, Partridge $M$ and Rojas R: The role of angiogenesis in the spread of oral squamous cell carcinoma. Br J Oral Maxillofac Surg 34: 37-41, 1996. PMID: 8645680. DOI: 10.1016/s0266-4356(96)90133-3

55 Folkman J, Watson $\mathrm{K}$ and Ingber D: Induction of angiogenesis during the transition from hyperplasia to neoplasia. Nature 339: 58-61, 1989. PMID: 2469964. DOI: 10.1038/339058a0
56 Fujisawa K: Relationship between the amount of accumulation of cisplatin and the archtecture of blood vessels in rabbit VX 2 tongue cancer. Dent J Iwate Med Univ 24: 1-15, 1999. DOI: 10.20663/iwateshigakukaishi.24.1_1

57 Tomasek JJ, Gabbiani G, Hinz B, Chaponnier C and Brown RA: Myofibroblasts and mechano- regulation of connective tissue remodelling. Nat Rev Mol Cell Biol 3: 349-363, 2002. PMID: 11988769. DOI: $10.1038 / \mathrm{nrm} 809$

58 Räsänen $\mathrm{K}$ and Vaheri A: Activation of fibroblasts in cancer stroma. Exp Cell Res 316: 2713-2722, 2010. PMID: 20451516. DOI: $10.1016 /$ j.yexcr.2010.04.032

59 Mhawech-Fauceglia P, Wang D, Samrao D, Kim G, Lawrenson $\mathrm{K}$, Meneses T, Liu S, Yessaian A and Pejovic T: Clinical implications of marker expression of carcinoma-associated fibroblasts (CAFs) in patients with epithelial ovarian carcinoma after treatment with neoadjuvant chemotherapy. Cancer Microenviron 7: 33-39, 2014. PMID: 24214412. DOI: 10.1007/ s12307-013-0140-4

60 Marsh D, Suchak K, Moutasim KA, Vallath S, Hopper C, Jerjes W, Upile T, Kalavrezos N, Violette SM, Weinreb PH, Chester KA, Chana JS, Marshall JF, Hart IR, Hackshaw AK, Piper K and Thomas GJ: Stromal features are predictive of disease mortality in oral cancer patients. J Pathol 223: 470-481, 2011. PMID: 21294121. DOI: $10.1002 /$ path. 2830

61 Fujii N and Shomori K: Cancer-associated fibroblasts and CD163positive macrophages in oral squamous cell carcinoma: their clinicopathological and prognostic significance. J Oral Pathol Med 41: 444-451, 2012. PMID: 22296275. DOI: 10.1111/j.1600-0714.2012.01127.x

62 Sanz-Moreno V, Gaggioli C, Yeo M, Albrengues J, Wallberg F, Viros A, Hooper S, Mitter R, Féral CC, Cook M, Larkin J, Marais R, Meneguzzi G, Sahai E and Marshall CJ: ROCK and JAK1 signaling cooperate to control actomyosin contractility in tumor cells and stroma. Cancer Cell 20: 229-245, 2011. PMID: 21840487. DOI: $10.1016 /$ j.ccr.2011.06.018

63 Gaggioli C, Hooper S, Hidalgo-Carcedo C, Grosse R, Marshall JF, Harrington K and Sahai E: Fibroblast-led collective invasion of carcinoma cells with differing roles for RhoGTPases in leading and following cells. Nat Cell Biol 9: 1392-1400, 2007. PMID: 18037882. DOI: $10.1038 / \mathrm{ncb} 1658$

64 Camps JL, Chang SM, Hsu TC, Freeman MR, Hong SJ, Zhau HE, von Eschenbach AC and Chung LW: Fibroblast-mediated acceleration of human epithelial tumor growth in vivo. Proc Natl Acad Sci USA 87: 75-79, 1990. PMID: 2296606. DOI: 10.1073/pnas.87.1.75

65 Imai K: Matrix metalloproteinases and cancer cell invasion and metastasis. Tanpakushitsu Kakusan Koso 42: 1694-1700, 1997. PMID: 9279101 